This document was prepared in conjunction with work accomplished under Contract No. DE-AC09-96SR18500 with the U. S. Department of Energy.

\title{
DISCLAIMER
}

This report was prepared as an account of work sponsored by an agency of the United States Government. Neither the United States Government nor any agency thereof, nor any of their employees, makes any warranty, express or implied, or assumes any legal liability or responsibility for the accuracy, completeness, or usefulness of any information, apparatus, product or process disclosed, or represents that its use would not infringe privately owned rights. Reference herein to any specific commercial product, process or service by trade name, trademark, manufacturer, or otherwise does not necessarily constitute or imply its endorsement, recommendation, or favoring by the United States Government or any agency thereof. The views and opinions of authors expressed herein do not necessarily state or reflect those of the United States Government or any agency thereof.

This report has been reproduced directly from the best available copy.

Available for sale to the public, in paper, from: U.S. Department of Commerce, National Technical Information Service, 5285 Port Royal Road, Springfield, VA 22161, phone: (800) 553-6847, fax: (703) 605-6900

email: orders@ntis.fedworld.gov

online ordering: http://www.ntis.gov/help/index.asp

Available electronically at http://www.osti.gov/bridge

Available for a processing fee to U.S. Department of Energy and its contractors, in paper, from: U.S. Department of Energy, Office of Scientific and Technical Information, P.O. Box 62, Oak Ridge, TN 37831-0062,

phone: (865)576-8401,

fax: (865)576-5728

email: $\underline{\text { reports@ adonis.osti.gov }}$ 
KEY WORDS: Performance Assessment

Evaluation

LLW Disposal

Reactor Scrap Metal

\title{
Evaluation of Proposed New LLW Disposal Activity
}

Disposal of No Dose/Low Dose Scrap Metal in Slit Trenches

\author{
Author \\ James R. Cook \\ Westinghouse Savannah River Company \\ Savannah River Technology Center \\ Aiken, SC 29808
}

December 16, 2003

Westinghouse Savannah River Company

Savannah River Site

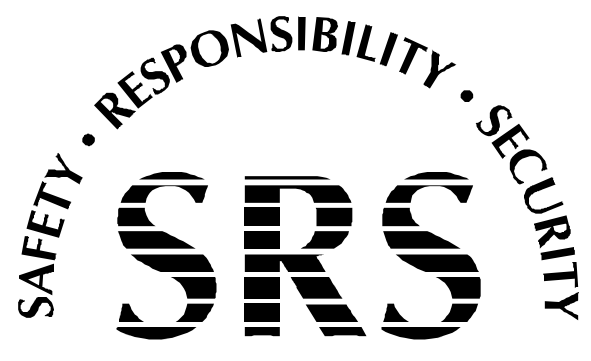

Aiken, SC 29808 


\section{REVIEWS AND APPROVALS}

\section{Author}

James R. Cook, Author

Date

Waste Disposal and Environmental Development

\section{SRTC Review/Approvals}

W. E. Stevens, Level 3

Waste Processing Technology

B. T. Butcher, Level 4 and Reviewer

Date

Waste Disposal and Environmental Development

\section{Solid Waste Division Approval}

W. T. Goldston

Date

Solid Waste Division

L.T. Reid, Solid Waste Division Engineering Manager

Date

K.A. Stone, Solid Waste Facilities Operations Safety Committee Chairman

Date 


\section{Summary}

There is an inventory of activated scrap metal in the 105-L Disassembly Basin. Approximately $1,600 \mathrm{ft}^{3}$ of the material is characterized as "No Dose/Low Dose" and consists mainly of activated aluminum and aluminum alloy pieces and parts and no stainless steel with a dose rate less than $200 \mathrm{mR} / \mathrm{hr}$. Contaminants in the activated metal will leach more slowly than will contaminants in generic waste. The change in the leach rate will affect analyses for the groundwater pathway and intruder scenarios. For this evaluation, the slower leach rate from the activated metal waste will be neglected for the groundwater pathway, which is conservative because the higher leach rate used tends to produce higher groundwater concentrations and lower inventory limits. For this evaluation, the leach rate was set to zero for intruder scenarios, which is conservative for the inadvertent intruder because a slower leach rate will result in higher levels of radionuclides in the waste zone.

The evaluation concludes that the existing limits are applicable to the disposal of No Dose/Low Dose activated scrap metal in slit trenches so that a Special Analysis is not needed to dispose of this waste stream

\section{Introduction}

Activated metal is a special waste that requires evaluation for disposal. Contaminants in the activated metal will leach more slowly than will contaminants in generic waste. The change in the leach rate will affect analyses for the groundwater pathway and intruder scenarios. For this evaluation, the slower leach rate will be neglected for the groundwater pathway, thus producing higher groundwater concentrations and lower inventory limits than would be expected. For this evaluation, the slower leach rate was set to zero for intruder scenarios.

Analyses for all pathways other than the intruder scenarios do not change from earlier Performance Assessments (PAs) and Special Analyses (SAs). The intruder analyses change by neglecting leaching, thus only allowing decay to reduce the fraction of contaminant remaining at the time of the hypothetical intrusion. If the fraction of contaminant remaining is dominated by decay rather than leaching then the inventory limits of an intruder scenario will remain unchanged.

Limits for each pathway are compared and the most restrictive limit is assigned as the operational inventory limit. In this evaluation the operational inventory limit will only change if an intruder scenario produces the most restrictive new limit and that limit is lower than the old operational inventory limit.

The preferred disposal unit for the No Dose/Low Dose activated scrap metal is a slit trench.

The proposed activity is formally stated below and contaminants of concern are described. Each pathway analysis is described with results of calculations for the intruder scenarios. Tables of limits for each pathway and the selection of the most restrictive pathway are provided. Finally, projected inventories are compared against those limits to estimate the inventory consumption. 


\section{Description of Proposed Activity}

The proposed activity (Reed, 2003) is to dispose of No Dose/Low Dose activated metals in a slit trench.

\section{Contaminants of Concern}

Spent Fuel Project personnel identified the following contaminants of concern (Ellis, 2003):

H-3

C-14

$\mathrm{Fe}-55$

Co-60

$\mathrm{Ni}-63$

$\mathrm{Sb}-125$

$\mathrm{Pu}-239$

The progeny are included in the analysis of the parent, thus they will not be discussed further.

Fe-55 and Sb-125 were screened out in the performance assessment because of their short half lives, 2.7 years and 2.8 years, respectively and are not considered further in this analysis.

\section{Performance Assessment Pathway Review}

Air Pathways

A Special Analysis (Cook, 2002) that corrected and updated E-Area disposal limits provided the applicable limits for the air pathway analysis (e.g., Table 5.2.1 in the SA) for generic waste. Each disposal unit showed a limit for $\mathrm{C}-14$ of $2.7 \mathrm{Ci}$ for the air pathway. This limit does not change because the air analysis does not consider leaching to reduce the inventory. The C-14 in activated metal would be less available for release to the air pathway than generic waste. Therefore the use of the current air pathway limit is conservative.

Radon

The Performance Assessment (McDowell-Boyer et al., 2000) analyzed the radon produced solely at 10,000 years from an initial source of U-234. Solid Waste determined that U-234 was not a contaminant of concern for No Dose/Low Dose activated scrap metal, thus the radon pathway is not considered further.

Groundwater

As stated above, the groundwater analysis did not change from the PA. This approach tends to be conservative, because no credit is taken for the slower leaching that is expected from the activated metal.

\section{Inadvertent Intruder}

The trench disposal unit intruder analysis calculations were rerun for the contaminants of concern with no leaching, that is the Inventory Reduction Factor in the calculation is determined using only radioactive decay to decrease the inventory over time. The results are shown in Table 1. 
Table 1. Results of Revised Intruder Calculations

\begin{tabular}{|c|c|c|c|c|c|c|}
\hline Radionuclide & $\begin{array}{l}\text { Inventory } \\
\text { Reduction } \\
\text { Factor at } \\
100 \text { years }\end{array}$ & $\begin{array}{l}\text { Inventory } \\
\text { Reduction } \\
\text { Factor at } \\
700 \text { years }\end{array}$ & $\begin{array}{l}\text { Resident } \\
\text { Limit at } 100 \\
\text { years }(\mathrm{Ci} / 5 \\
\text { trenches or } 1 \\
\text { Engineered } \\
\text { Trench) }\end{array}$ & $\begin{array}{c}\text { Agriculture } \\
\text { Limit at } 700 \\
\text { years }(\mathrm{Ci} / 5 \\
\text { trenches or } 1 \\
\text { Engineered } \\
\text { Trench) }\end{array}$ & $\begin{array}{l}\text { Post Drilling } \\
\text { Limit at } 100 \\
\text { years }(\mathrm{Ci} / 5 \\
\text { trenches or } 1 \\
\text { Engineered } \\
\text { Trench) }\end{array}$ & $\begin{array}{l}\text { Overall Intruder } \\
\text { Limit (Ci/5 } \\
\text { trenches or } 1 \\
\text { Engineered } \\
\text { Trench) }\end{array}$ \\
\hline $\mathrm{H}-3$ & $3.5 \mathrm{E}-03$ & $7.0 \mathrm{E}-18$ & No Limit & $1.8 \mathrm{E}+20$ & $1.9 \mathrm{E}+06$ & $1.9 \mathrm{E}+06$ \\
\hline C-14 & $9.9 \mathrm{E}-01$ & $9.2 \mathrm{E}-01$ & No Limit & $3.5 \mathrm{E}+02$ & $1.7 \mathrm{E}+03$ & $3.5 \mathrm{E}+02$ \\
\hline Co-60 & $2.0 \mathrm{E}-06$ & $1.1 \mathrm{E}-40$ & $2.1 \mathrm{E}+09$ & $2.3 \mathrm{E}+42$ & $7.3 \mathrm{E}+08$ & $7.3 \mathrm{E}+08$ \\
\hline $\mathrm{Ni}-63$ & $5.0 \mathrm{E}-01$ & 7.9E-03 & No Limit & $3.3 \mathrm{E}+06$ & $2.8 \mathrm{E}+05$ & $2.8 \mathrm{E}+05$ \\
\hline $\mathrm{Pu}-239$ & $1.0 \mathrm{E}+00$ & $9.8 \mathrm{E}-01$ & No Limit & $1.3 \mathrm{E}+02$ & $1.1 \mathrm{E}+03$ & $1.3 \mathrm{E}+02$ \\
\hline
\end{tabular}

Table 2 compares the revised intruder limits with the current trench limits. Both tritium and $\mathrm{Pu}$ 239 remain limited by groundwater, and C-14 remains limited by the air pathway. The limits for Co-60 and Ni-63 are unchanged. In the Performance Assessment, these radionuclides were screened from the groundwater analysis and therefore no leaching fraction was determined and the only depletion used in the intruder analysis was radioactive decay. The result is that this analysis yields the same limits as the performance assessment. Therefore the limits do not change and a Special Analysis is not needed to dispose of this waste form.

Table 2. Inventory Limits for Slit Trenches and Engineered Trenches; Comparison of PA Limits to Activated Metal Limits

\begin{tabular}{|c|c|c|c|c|}
\hline Radionuclide & PA Trench Limit & $\begin{array}{l}\text { PA Limiting } \\
\text { Pathway }\end{array}$ & $\begin{array}{l}\text { Activated Metal } \\
\text { Intruder } \\
\text { Trench Limit }\end{array}$ & $\begin{array}{l}\text { Activated Metal } \\
\text { Limiting Intruder } \\
\text { Scenario }\end{array}$ \\
\hline $\mathrm{H}-3$ & $6.3 \mathrm{E}+00$ & gw & $1.9 \mathrm{E}+06$ & post drilling \\
\hline C-14 & $2.7 \mathrm{E}+00$ & air & $3.5 \mathrm{E}+02$ & agriculture \\
\hline Co-60 & $7.3 \mathrm{E}+08$ & post drilling & $7.3 \mathrm{E}+08$ & post drilling \\
\hline Ni-63 & $2.8 \mathrm{E}+05$ & post drilling & $2.8 \mathrm{E}+05$ & post drilling \\
\hline $\mathrm{Pu}-239$ & $1.3 \mathrm{E}+02$ & agriculture & $1.3 \mathrm{E}+02$ & agriculture \\
\hline
\end{tabular}

Table 3 shows that the sum of fractions represented by the No Dose/Low Dose activated scrap metal is very small.

\begin{tabular}{|l|r|r|r|}
\hline Table 3. Sum of Fractions Represented by No Dose/Low Dose Activated Scrap \\
Metal
\end{tabular}




\section{Evaluation}

1. Does the proposed activity involve a change to the Performance Assessment or exceed PA performance measures/conclusions?

No. Existing limits for intruder scenarios have been shown to apply to No Dose/Low Dose activated scrap metal.

2. Does the proposed activity involve a:

a. change to the basic disposal concept as described in the PA?

No. Existing trench disposal units and radionuclides are considered.

b. change to the analyses or radionuclide limits as described in the PA?

No. The analysis demonstrates the existing limits can be applied to No Dose/Low Dose activated scrap metal.

c. change in the disposal authorization (USDOE-HQ, 1999) that leads to a significant change in projected dose?

No. The proposed activity will not result in a significant change in projected dose.

d. change in the results in the approved PA that is greater than $10 \%$ ?

No. The proposed activity will not cause the results in the PA to change more than $10 \%$.

e. change of greater than $10 \%$ in the dose calculated in the approved PA?

No. The proposed activity will not increase the dose calculated in the PA for any isotope by more than $10 \%$.

f. Does the proposed activity modify the analysis or conclusions provided in the Composite Analysis (WSRC, 1997 and Cook, et al., 1999)?

No. The projected inventories are very low relative to the inventory limits, thus the analysis and conclusions of the CA are not modified.

g. change to the Disposal Authorization Statement (USDOE-HQ, 1999)?

No. The proposed activity does not necessitate a change to the Disposal Authorization Statement.

\section{Conclusion}

The proposed activity, disposing of No Dose/Low Dose activated scrap metal in slit trenches, can be implemented using existing radionuclide inventory limits. 


\section{References}

Cook, J.R., 2002. Special Analysis: Correction and Update of E-Area Disposal Limits. WSRCTR-2002-00047, Rev. 2. Savannah River Laboratory, Westinghouse Savannah River Company, Aiken, SC., May 2.

Cook, J.R., E.L. Wilhite, and L.B. Collard, 1999. Addendum to the Composite Analysis for the EArea Vaults and Saltstone Disposal Facilities. WSRC-RP-99-00844, Rev. 0. Savannah River Laboratory, Westinghouse Savannah River Company, Aiken, SC., September 23.

Ellis, Michael, 2003. SW FOSC - No Dose/Low Dose Narrative, E-mail to Shawn Reed, May 5, 2003.

McDowell-Boyer, L., A.D. Yu, J.R. Cook, D.C. Kocher, E.L. Wilhite, H. Holmes-Burns and K.E. Young, Radiological Performance Assessment for the E-Area Low-Level Waste Facility. WSRC-RP-94-218, Rev. 1. Westinghouse Savannah River Company, Aiken, SC., January 31.

Reed, S.R., 2003. Categorical Exclusion Unreviewed Safety Question, USQ-SWE-2002-0097, Sequence Number 2770, May 20 (attached).

USDOE-HQ, 1999. Disposal Authorization Statement for the Department of Energy Savannah River Site E-Area Vaults and Saltstone Disposal Facilities, September 28.

WSRC, 1997. Westinghouse Savannah River Company Composite Analysis E-Area Vaults and Saltstone Disposal Facilities, WSRC-RP-97-311, Rev. 0, September. 


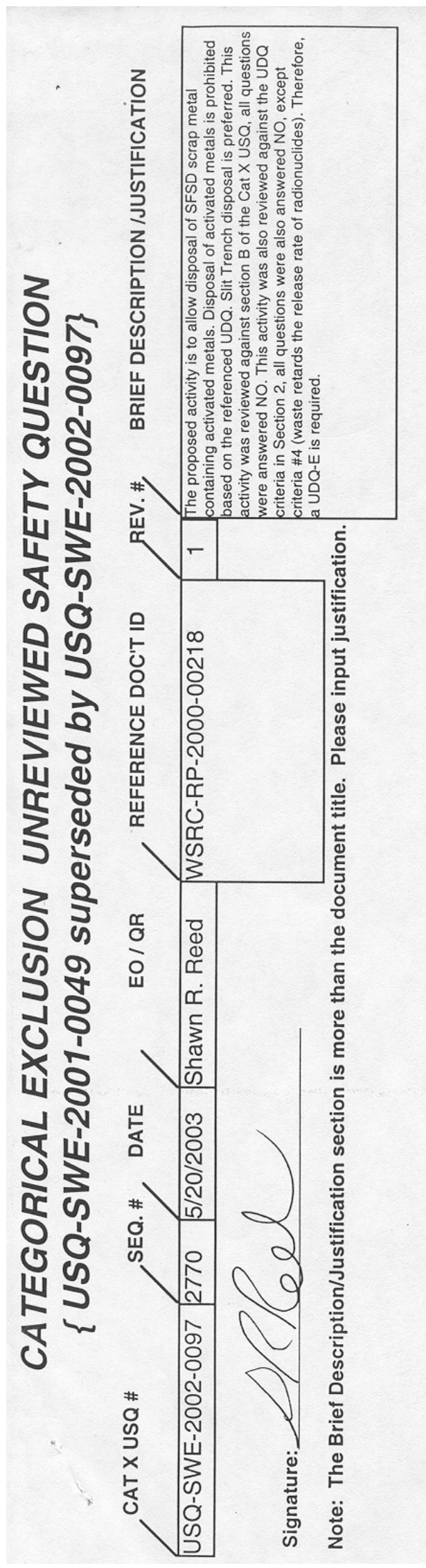




\section{Design Review Instructions}

Review instructions for Evaluation of Proposed New LLW Disposal Activity: Disposal of No Dose/Low Dose Scrap Metal in Slit Trenches.

1. Check the assumption regarding how the analysis for No Dose/Low Dose activated scrap metal should differ from generic waste

2. Check the equation used

3. Check all inputs and results in tables

4. Check that the inventory limits do not change.

\section{Design Review performed by Tom Butcher}

1. Check the assumption regarding how the analysis for beneficial reuse containers should differ from generic waste.

2. Check the equation used.

3. Check all inputs and results in tables.

4. Check that inventory limits do not change. 
Jim: The following are the results of the Reactor Scrap UDQE design check:

1. Check the assumption regarding how the analysis for reactor scrap should differ from generic waste.

The assumption made is that radionuclides are held up much longer in activated metal (reactor scrap) than generic waste that is assumed in the PA. Thus more radionuclides are available in the waste zone for potential inadvertant intruders. The treatment of this phenomenon by assuming that no leaching takes place, only decay, is conservative for the intruder analysis. On the other hand, leaching, as in the case of generic waste, is assumed for the groundwater analysis which is also conservative for that pathway.

2. Check the equations used.

All spreadsheet equations related to the pathways in question were checked and confirmed to be correct.

3. Check all inputs and results in tables.

The source of all inputs used in the equations were checked to confirm that the correct inputs were used. This involved going back to the E-Area PA (WSRC-RP-94-218, rev.1), then New Pu chemistry SA (WSRC-TR-2002-00154) and the SA on Correction and Update of E-Area Disposal Limits (WSRC-TR-2002-00047). Transcription of information from the excel spreadsheet to the tables in the UDQE and between tables within the UDQE was checked. All entires were found to be correct with exception to those items noted in the marked up copy of the UDQE placed on your chair.

The results of pertinent equations in spreadsheet calculations were cross-checked by hand calculations and found to be correct.

4. Check that inventory limits do not change.

Inventory limits in the UDQE were compared with the appropriate source document and found to have not changed. 